\title{
The Effect of Fingolimod (FTY720) Treatment on Liver Enzyme Levels in Relapsing-Remitting Multiple Sclerosis Patients
}

\author{
Fingolimod (FTY720) Tedavisinin Relapsing-Remitting Multipl Skleroz Hastalarında Karaciğer \\ Enzim Düzeylerine Etkisi
}

\author{
Duygu TAP ${ }^{1}$ \\ (D) 0000-0002-8004-7970 \\ Menderes Yusuf TERZi $\dot{I}^{1,2}$ \\ (D) 0000-0001-8478-0451 \\ Taşkın DUMAN ${ }^{3}$ \\ (D) 0000-0002-6552-4193
}

\begin{abstract}
${ }^{1}$ Hatay Mustafa Kemal University Graduate School of Health Sciences Department of Molecular Biochemistry and Genetics, Hatay, Turkey

${ }^{2}$ Hatay Mustafa Kemal University Faculty of Medicine Department of Medical Biology, Hatay, Turkey

${ }^{3}$ Hatay Mustafa Kemal University Faculty of Medicine Department of Neurology, Hatay, Turkey
\end{abstract}

\section{Corresponding Author Sorumlu Yazar \\ Menderes Yusuf TERZİ \\ menderesyusufterzi@gmailcom}

Received / Gelis Tarihi : 30.07 .2020 Accepted / Kabul Tarihi : 23.10.2020 Available Online /

Çevrimiçi Yayın Tarihi : 25.12.2020

\begin{abstract}
Aim: Multiple sclerosis (MS) is a chronic inflammatory pathology affecting the central nervous system. Many therapeutic options have been approved against MS until today. In this study, it was aimed to investigate the effect of fingolimod treatment (FT) on the liver enzyme levels of relapsing-remitting multiple sclerosis (RRMS) patients.

Material and Methods: Body mass index, FT $(0.5 \mathrm{mg} /$ day $)$ duration, and liver enzyme (alanine aminotransferase, ALT; gamma glutamyl transferase, GGT) levels of 102 RRMS patients ( 66 female, 36 male, mean age was $40.9 \pm 10.9$ years) were gathered from polyclinic records retrospectively.

Results: The FT duration of MS patients was between 0.5 and 6 years. Increased ALT and GGT levels were detected in RRMS patients after $>3$ month-long FT. After FT, ALT and GGT levels elevated in males almost 2 times higher than in females. It was observed that ALT and GGT levels increased by 1.3 and 1.5 times in females, while 1.6 and 1.9 times in males, respectively. Of the MS patients with increased transaminases post-FT, 7 (23.3\%) males and $8(17.4 \%)$ females were at upper limit of normal for ALT whereas $9(34.6 \%)$ males and 14 (32.6\%) females as for GGT. Age and FT duration did not affect ALT and GGT levels.

Conclusion: Overall, FT elevated ALT and GGT levels of RRMS patients. Thus, it is of high importance to monitor MS patients throughout FT. So that, we suggest tracking ALT and GGT levels during and after FT to prevent possible liver damage or the occurrence of other systemic diseases.
\end{abstract}

Keywords: Relapsing-remitting multiple sclerosis; fingolimod; liver enzyme; ALT; GGT.

\section{ÖZ}

Amaç: Multipl skleroz (MS) merkezi sinir sistemini etkileyen kronik inflamatuvar bir patolojidir. Günümüze kadar MS'e karşı birçok tedavi seçeneği onaylanmıştır. Bu çalışmada, fingolimod tedavisinin (FT) relapsing-remitting multipl skleroz (RRMS) hastalarının karaciğer enzim düzeylerine etkisinin araştırılması amaçlanmıştır.

Gereç ve Yöntemler: Yüz iki RRMS hastasının ( 66 kadın, 36 erkek, ortalama yaş 40,9 $9 \pm 10,9$ yıl) vücut kitle indeksi, FT ( $0,5 \mathrm{mg} /$ gün) süreleri ve karaciğer enzim (alanin aminotransferaz, ALT; gama glutamil transferaz, GGT) seviyeleri poliklinik kayıtlarından geriye dönük olarak incelendi.

Bulgular: MS hastalarının FT süresi 0,5 ile 6 yıl arasındaydı. Üç ay ve daha fazla FT süresi olan RRMS hastalarında ALT ve GGT seviyelerinin arttı̆g tespit edildi. FT sonrası, ALT ve GGT seviyeleri erkeklerde kadınlara kıyasla yaklaşık olarak 2 kat daha yüksekti. Kadınlarda ALT ve GGT seviyelerinin sirasiyla 1,3 ve 1,5 kat, erkeklerde ise bu seviyelerin 1,6 ve 1,9 kat arttığı görüldü. FT sonrası transaminaz seviyesi artan MS hastalarından $9(\% 34,6)$ erkek ve 14 $(\% 32,6)$ kadın GGT için normalin üst seviyesindeyken, $7(\% 23,3)$ erkek ve $8(\% 17,4)$ kadın ALT için normalin üst seviyesindeydi. Yaş ve FT süresi, ALT ve GGT seviyelerini etkilemiyordu.

Sonuç: Sonuç olarak, FT RRMS hastalarının ALT ve GGT seviyelerini yükseltmiştir. Bundan dolayı, MS hastalarının FT süresince takibi oldukça önemlidir. Bu yüzden, MS hastalarında olası karaciğer hasarı ya da diğer sistemik hastalıkların önlenmesi için FT sırasında ve sonrasında ALT ve GGT seviyelerinin takip edilmesini öneriyoruz.

Anahtar kelimeler: Relapsing-remitting multipl skleroz; fingolimod, karaciğer enzimi; ALT; GGT. 


\section{INTRODUCTION}

Multiple sclerosis (MS) is a central nervous system (CNS) disease characterized by inflammation, demyelination, and neurodegeneration (1). Several medications that change the course of MS have been identified since the discovery of the disease. But today, despite great advances in MS therapy, we are still not at the desired point regarding a long-lasting cure. Fingolimod is the first oral medication approved by the United States Food and Drug Administration to attenuate seizures and disability rates in relapsing-remitting multiple sclerosis (RRMS) type (2). Fingolimod acts as a modulator of sphingosine-1-phosphate (S1P) that is found in immune system cells (3). S1P is involved in several biological processes via interacting with G-protein-coupled S1P receptor. In the immune system, $\mathrm{S} 1 \mathrm{P}$ activates lymphocytes by binding to their S1P receptors and also blocks their release from lymph nodes (4-6). Eventually, autoreactive B and $\mathrm{T}$ lymphocytes are blocked to reach to CNS and cause inflammation (7).

Although the effectiveness and reliability of fingolimod treatment (FT) against MS have been shown previously $(8,9)$, there are also side effects of this immunomodulatory drug such as altered liver enzyme levels (10). In previous studies comparing the effect of fingolimod with placebo, $0.5 \mathrm{mg} /$ day FT caused asymptomatic increases in liver transaminase levels of the patients with $7-8 \%$ of MS patients having 3 -fold and $2-4 \%$ having 5-fold higher levels than the upper limits of normal (ULN). These increments in liver enzyme levels were observed $~ 3-4$ months after the start of FT and reduced to within normal limits (WNL) $\sim 2-3$ months after the cessation of FT (11-13).

It is of pivotal importance to know and monitor the side effects of fingolimod as an immunosuppressive drug in MS therapy. It has been previously well documented by "Central and East European (CEE) MS Expert Group" that 3 to 4 months of FT caused asymptomatic elevations in liver enzyme levels (14). On the other hand, the asymptomatic elevations in liver transaminases can highly vary depending on the studied population $(15,16)$. In this context, the aim of this retrospective study was to analyze alanine aminotransferase (ALT) and gamma-glutamyl transferase (GGT) liver enzyme levels before and after FT in RRMS patients.

\section{MATERIAL AND METHODS \\ Patients}

Permission for this study was obtained from Non-invasive Clinical Studies Ethical Committee in Hatay Mustafa Kemal University (02/18, 17/01/2019). 102 patients, who were 18-65 year-old, diagnosed with RRMS based on the McDonald 2017 criteria (17), and started their first FT in Hatay Mustafa Kemal University Medical Faculty Research Hospital Neurology Polyclinic between 20132019 were included in this retrospective study. MS patients medicated with anti-inflammatory drugs or who had any disease or disease history affecting liver enzyme levels such as chronic liver disease, chronic inflammatory disease, and cancer were excluded from the study (Figure 1).

\section{Data Collection}

We collected the medical records of RRMS patients including age, sex, FT (0.5 mg/day) duration, body mass index (BMI), and ALT and GGT levels before and at least 3 months after FT (the first measurements post-FT) by retrospective inquiry of the clinical patient database of the Neurology Polyclinic in the Research Hospital of Hatay Mustafa Kemal University. The following reference ranges of Hatay Mustafa Kemal University Research Hospital were used for liver enzyme parameters in this study: For ALT levels, 10-49 U/L WNL and >49 U/L ULN in males and females; for GGT levels, 9-36 U/L WNL and $>36 \mathrm{U} / \mathrm{L}$ ULN in females and 12-64 U/L WNL and >64 U/L ULN in males.

\section{Statistical Analysis}

The normal distribution of the variables was assessed using Kolmogorov-Smirnov test. We used non-parametric tests since our data did not exhibit normal distribution. The data were expressed as mean \pm standard deviation (SD) and median (with interquartile range and minimum-maximum values) for continuous variables, and as percentage for categorical variables. Wilcoxon signed-rank test was used to compare the liver enzyme levels before and after FT. Spearman's correlation test was used to analyze any association of liver enzyme levels with age and FT duration. A p value of less than 0.05 was accepted as statistically significant. All statistical analyses were performed using SPSS v.22.0 statistical package.

\section{RESULTS}

The baseline characteristics of the RRMS patients are shown in Table 1. Of the 102 RRMS patients included in the present study, $66(64.7 \%)$ were female and $36(35.3 \%)$ were male. The mean age of MS patients, who were between 18 and 63 years old, was $40.9 \pm 10.9,42.4 \pm 10.8$ for female and $38.1 \pm 10.8$ for male patients. There was no significant difference between the mean ages of males and females $(p=0.054)$. The FT duration of MS patients in our study was between 0.5 and 6 years, and the mean FT duration was $1.5 \pm 1.2$ years.

We observed that the ALT and GGT levels of MS patients increased significantly after FT compared to before FT $(\mathrm{p}<0.001$, Figure 2, Table 2).

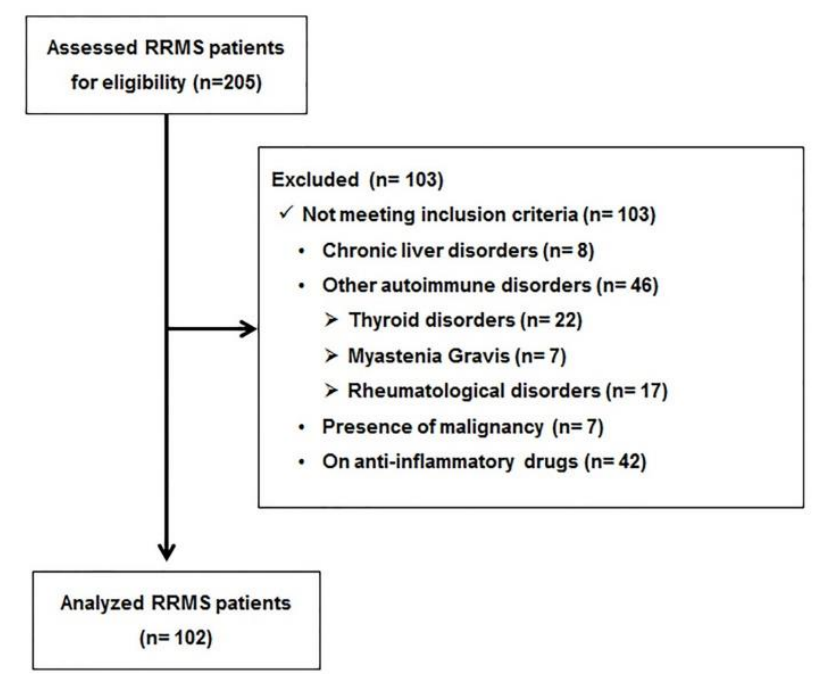

Figure 1. CONSORT flow diagram indicating the inclusion/exclusion criteria of RRMS patients 
Table 1. Baseline characteristics of RRMS patients

\begin{tabular}{lc}
\hline Gender, $\mathrm{n}(\%)$ & $66(64.7)$ \\
$\quad$ Female & $36(35.3)$ \\
$\quad$ Male & \\
Age (year), mean $\pm \mathrm{SD}$ & $40.9 \pm 10.9$ \\
$\quad$ General & $42.4 \pm 10.8$ \\
$\quad$ Female & $38.1 \pm 10.8$ \\
$\quad$ Male & \\
BMI $\left(\mathrm{kg} / \mathrm{m}^{2}\right)$, mean $\pm \mathrm{SD}$ & $26.8 \pm 3.3$ \\
$\quad$ General & $27.4 \pm 2.6$ \\
$\quad$ Female & $23.1 \pm 1.8$ \\
$\quad$ Male & $1.5 \pm 1.2$ \\
FT period (year), mean $\pm \mathrm{SD}$ &
\end{tabular}

RRMS: relapsing-remitting multiple sclerosis, SD: standard deviation, BMI: body mass index, FT: fingolimod treatment
Of the MS patients with increased ALT levels, 38 (82.6\%) of females were WNL and $8(17.4 \%)$ of them exceeded ULN, while $23(76.7 \%)$ of males were WNL and 7 (23.3\%) of them exceeded ULN. From the MS patients with increased GGT levels, $29(67.4 \%)$ of females were WNL and $14(32.6 \%)$ of them exceeded ULN while $17(65.4 \%)$ of males were WNL and $9(34.6 \%)$ of them exceeded ULN.

There was no significant correlation of increased liver ALT and GGT levels with the age $(\mathrm{r}=-0.068, \mathrm{p}=0.559$ for ALT, and $r=-0.020, p=0.869$ for GGT) or with the FT duration $(\mathrm{r}=-0.129, \mathrm{p}=0.268$ for ALT, and $\mathrm{r}=0.122$, $\mathrm{p}=0.316$ for GGT).

Table 2. ALT/GGT levels in general and in female and male RRMS patients pre- and post-FT

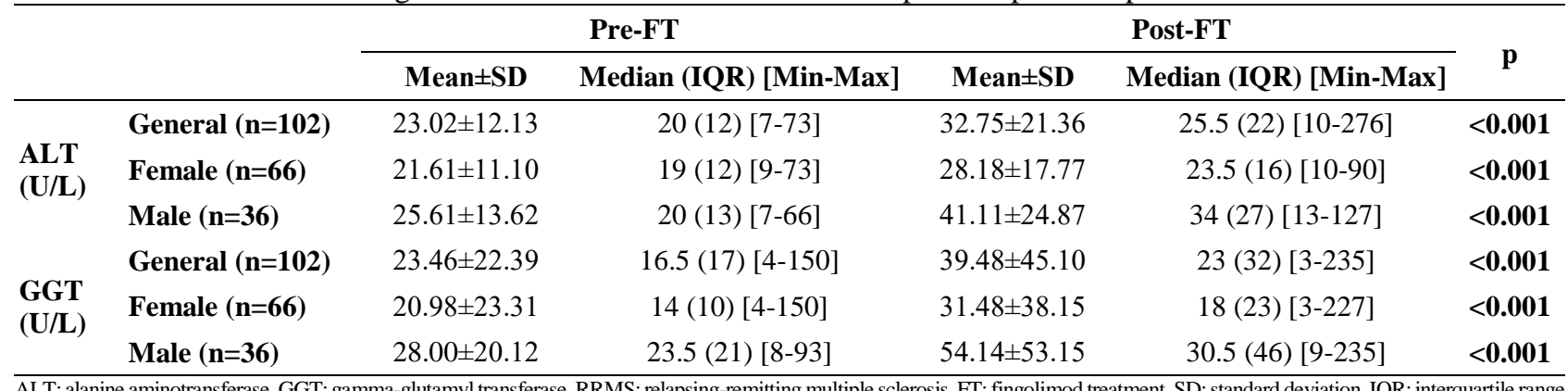
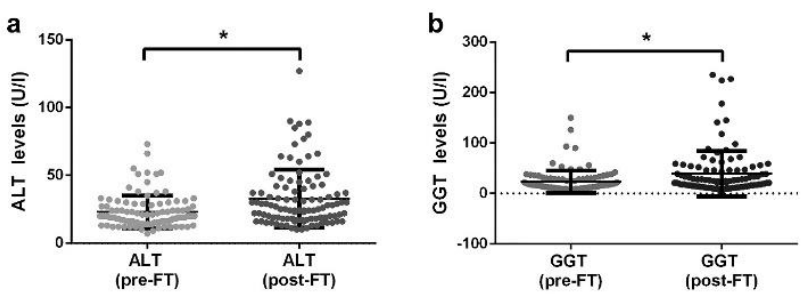

Figure 2. Liver enzyme levels before and after FT in RRMS patients, a) ALT, b) GGT, *: p<0.001, FT: fingolimod treatment, RRMS: relapsing-remitting multiple sclerosis, ALT: alanine aminotransferase, GGT: gamma-glutamyl transferase

\section{DISCUSSION}

FT, despite well-tolerated in MS patients, has several side effects including macular edema, lymphopenia, hypertension and more commonly increased liver enzymes $(6,18,19)$. In the present study, we retrospectively evaluated the effect of FT on liver enzyme levels (ALT and GGT) in RRMS patients and observed that both ALT and GGT were increased in the patients.

The effects of FT on liver enzyme levels of MS patients have been shown in previous studies. In a study conducted with Japanese RRMS patients, the increase in enzyme levels was the most common side effect of $0.5 \mathrm{mg} /$ day FT for 12 months (20). In the same study, it was also observed that ALT and AST levels of MS patients reached peak levels at 3 months of FT while GGT levels peaked after 6.5 months of FT and in the patients with persistently high enzyme levels FT was withdrawn. In another study with 122 RRMS patients that evaluated the effectiveness and reliability of FT, ALT and GGT levels in $\sim 25 \%$ of MS patients increased significantly (21). In the present study, we also compared the liver enzyme levels of RRMS patients before and after FT and observed, as consistent with the previous studies, that ALT and GGT levels elevated significantly with FT compared to the baseline. It has been reported that ALT and AST levels can change significantly among different populations $(15,16)$. Despite limited studies concerning confounder effects of demographic features on liver enzyme levels after FT, in general, increased ALT levels were observed $15 \%$ more frequently in male patients than in females $(22,23)$. Besides, other studies investigating the effect of fingolimod on MS patients reported that the patients with increased liver enzymes mostly consisted of males $(24,25)$. Similarly, we also observed that ALT levels after FT increased significantly in $80.5 \%$ of males while this ratio was $68.1 \%$ in females. As to GGT levels, FT led to elevations in $\sim 64 \%$ of both males and females. We also detected that ALT and GGT levels after FT in males were $\sim 1.4$ and 1.7 times higher respectively than in females. Among female MS patients, the mean ALT and GGT levels after FT were $\sim 1.3$ and 1.5 times higher respectively than before FT, while among male MS patients, the mean ALT and GGT levels after FT were $~ 1.6$ and 1.9 times higher respectively than before FT. In a controlled study conducted in 358 RRMS patients, ALT levels showed a dose-dependent elevation after FT and increased in 29 patients, exceeded ULN in 25 patients by 3 -fold and 5 -fold in 8 patients (12). In a similar study conducted in Latin American RRMS patients, ALT levels after FT reached 3, 5-, and 10-times of ULN (26). In parallel with previous studies, we noticed that $23.4 \%$ and $34.6 \%$ of male MS 
patients exceeded ULN of ALT and GGT levels respectively, whereas $17.9 \%$ and $32.6 \%$ of female MS patients exceeded ULN of ALT and GGT levels respectively. A previous report underlined that monitoring liver enzymes during/after FT is important to sustain a functional liver. Based on this report by the CEE MS Expert Group, liver transaminases should be screened periodically (i.e. at moth 1, 3, 6 post-FT) and FT should be discontinued if the liver enzyme levels exceed five times ULN, which should normally return to baseline levels within two months, to prevent hepatic failure (14). Furthermore, owing to its prominent anti-inflammatory and neuroprotective effects, FT was also utilized as a treatment option in other neurodegenerative and/or neuroinflammatory disease models such as schizophrenia, optic neuritis, Alzheimer's disease, Parkinson's disease, epilepsy, etc. $(6,27)$. In a phase-II trial study testing the safety and efficacy of FT on amyotrophic lateral sclerosis (ALS) patients, fingolimod was reported to be welltolerated in ALS patients and caused no similar side effects like in MS patients (28).

As to our knowledge, there is no study in the literature analyzing the correlation of increased levels of liver enzymes with the age of MS patients and FT duration. In the present study, there was no significant correlation of increased ALT and GGT levels with the age of RRMS patients or FT duration.

\section{CONCLUSION}

The present study confirmed that FT caused significant elevations in ALT and GGT levels of RRMS patients. For this reason, we suggest that ALT and GGT levels should be followed routinely during and after FT to prevent probable liver failures.

\section{Study Limitations}

In the present study, we included routinely analyzed liver enzyme levels in our polyclinic, i.e. ALT and GGT but not AST.

Ethics Committee Approval: The study was approved by the Ethics Committee of Hatay Mustafa Kemal University Faculty of Medicine (17.01.2019, 02/18).

Conflict of Interest: This manuscript was produced based on the master thesis of Duygu Tap, as the first author here, and all authors declare that there is no conflict of interest.

Financial Disclosure: None declared by the authors.

Acknowledgements: We thank to Dr. Marietta Zille $(\mathrm{PhD})$ (Institute for Experimental and Clinical Pharmacology and Toxicology, University of Lübeck, and Department of Translational Medicine and Cell Technology, Fraunhofer Research Institution for Marine Biotechnology EMB, Lübeck, Germany) for her valuable contributions in editing this manuscript.

\section{REFERENCES}

1. Leray E, Moreau T, Fromont A, Edan G. Epidemiology of multiple sclerosis. Rev Neurol (Paris). 2016;172(1):3-13.

2. Ingwersen J, Aktas O, Kuery P, Kieseier B, Boyko A, Hartung HP. Fingolimod in multiple sclerosis: mechanisms of action and clinical efficacy. Clin Immunol. 2012;142(1):15-24.

3. Cohen JA, Chun J. Mechanisms of fingolimod's efficacy and adverse effects in multiple sclerosis. Ann Neurol. 2011;69(5):759-77.

4. Matloubian M, Lo CG, Cinamon G, Lesneski MJ, Xu $\mathrm{Y}$, Brinkmann $\mathrm{V}$, et al. Lymphocyte egress from thymus and peripheral lymphoid organs is dependent on S1P receptor 1. Nature. 2004;427(6972):355-60.

5. Pitman MR, Woodcock JM, Lopez AF, Pitson SM. Molecular targets of FTY720 (fingolimod). Curr Mol Med. 2012;12(10):1207-19.

6. Bascuñana $\mathrm{P}$, Möhle L, Brackhan $\mathrm{M}$, Pahnke J. Fingolimod as a treatment in neurologic disorders beyond multiple sclerosis. Drugs R D. 2020;20(3):197207.

7. Schwab SR, Cyster JG. Finding a way out: lymphocyte egress from lymphoid organs. Nat Immunol. 2007;8(12):1295-301.

8. Yang CC, Ro LS, Tsai NW, Lin CC, Huang WN, Tsai $\mathrm{CP}$, et al. Real-world evidence on the safety and effectiveness of fingolimod in patients with multiple sclerosis from Taiwan. $\mathbf{J}$ Formos Med Assoc. 2020;120(1):542-50.

9. Lattanzi S, Rocchi C, Danni M, Taffi R, Cerqua R, Carletti $\mathrm{S}$, et al. Long-term outcome in multiple sclerosis patients treated with fingolimod. Mult Scler Relat Disord. 2020;45:102416.

10. Rojas JI, Patrucco L, Miguez J, Cristiano E. Realworld safety and patient profile of fingolimod in relapsing-remitting multiple sclerosis: a prospective analysis in Buenos Aires, Argentina. Clin Neuropharmacol. 2017;40(6):251-4.

11. Baroncini D, Zaffaroni M, Annovazzi PO, Baldini S, Bianchi A, Minonzio G, et al. A real world experience with fingolimod in active RRMS patients naïve to second-line agents: a 2 years, intention-to-treat, observational, single center study. Mult Scler Demyelinating Disord. 2016;1(1):4.

12. Calabresi PA, Radue EW, Goodin D, Jeffery D, Rammohan KW, Reder AT, et al. Safety and efficacy of fingolimod in patients with relapsing-remitting multiple sclerosis (FREEDOMS II): a double-blind, randomised, placebo-controlled, phase 3 trial. Lancet Neurol. 2014;13(6):545-56.

13. Saida T, Kikuchi S, Itoyama Y, Hao Q, Kurosawa T, Nagato $\mathrm{K}$, et al. A randomized, controlled trial of fingolimod (FTY720) in Japanese patients with multiple sclerosis. Mult Scler. 2012;18(9):1269-77.

14. Fazekas F, Berger T, Fabjan TH, Ledinek AH, Jakab G, Komoly S, et al. Fingolimod in the treatment algorithm of relapsing remitting multiple sclerosis: a statement of the Central and East European (CEE) MS Expert Group. Wien Med Wochenschr. 2012;162(1516):354-66.

15. Pratt DS, Kaplan MM. Evaluation of abnormal liverenzyme results in asymptomatic patients. $\mathrm{N}$ Engl $\mathrm{J}$ Med. 2000;342(17):1266-71.

16. Verslype C. Evaluation of abnormal liver-enzyme results in asymptomatic patients. Acta Clin Belg. 2004;59(5):285-9.

17. McNicholas N, Hutchinson M, McGuigan C, Chataway J. 2017 McDonald diagnostic criteria: A 
review of the evidence. Mult Scler Relat Disord. 2018;24:48-54.

18. Hersh CM, Hara-Cleaver C, Rudick RA, Cohen JA, Bermel RA, Ontaneda D. Experience with fingolimod in clinical practice. Int J Neurosci. 2015;125(9):67885.

19. Sonne SJ, Smith BT. Incidence of uveitis and macular edema among patients taking fingolimod $0.5 \mathrm{mg}$ for multiple sclerosis. J Ophthalmic Inflamm Infect. 2020;10(1):24.

20. Kira J, Itoyama Y, Kikuchi S, Hao Q, Kurosawa T, Nagato K, et al. Fingolimod (FTY720) therapy in Japanese patients with relapsing multiple sclerosis over 12 months: results of a phase 2 observational extension. BMC Neurol. 2014;14:21.

21. Yamout BI, Zeineddine MM, Tamim H, Khoury SJ. Safety and efficacy of fingolimod in clinical practice: The experience of an academic center in the Middle East. J Neuroimmunol. 2015;289:93-7.

22. Manni A, Direnzo V, Iaffaldano A, Di Lecce V, Tortorella C, Zoccolella S, et al. Gender differences in safety issues during fingolimod therapy: evidence from a real-life relapsing multiple sclerosis cohort. Brain Behav. 2017;7(10):e00804.

23. Quinn PG, Johnston DE. Detection of chronic liver disease: costs and benefits. Gastroenterologist.
1997;5(1):58-77.

24. Kappos L, Radue EW, O'Connor P, Polman C, Hohlfeld R, Calabresi P, et al. A placebo-controlled trial of oral fingolimod in relapsing multiple sclerosis. N Engl J Med. 2010;362(5):387-401.

25. Joni SS, Cheshmavar M, Shoureshi P, Zamani Z, Taoosi $\mathrm{N}$, Akbari M, et al. Effects of fingolimod treatments on alanine transaminase and aspartate transaminase levels in patients with multiple sclerosis. Int $\mathrm{J}$ Physiol Pathophysiol Pharmacol. 2020;12(3):88-94.

26. Ordoñez-Boschetti L, Rey R, Cruz A, Sinha A, Reynolds T, Frider N, et al. Safety and tolerability of fingolimod in Latin American patients with relapsingremitting multiple sclerosis: The Open-Label FIRST LATAM Study. Adv Ther. 2015;32(7):626-35.

27. Francis MM, Hummer TA, Liffick E, Vohs JL, Mehdiyoun NF, Visco AC, et al. Effects of fingolimod, a sphingosine-1-phosphate (S1P) receptor agonist, on white matter microstructure, cognition and symptoms in schizophrenia. Brain Imaging Behav. 2020; [Epub ahead of print]. doi: 10.1007/s11682-020-00375-7.

28. Berry JD, Paganoni S, Atassi N, Macklin EA, Goyal N, Rivner $\mathrm{M}$, et al. Phase IIa trial of fingolimod for amyotrophic lateral sclerosis demonstrates acceptable acute safety and tolerability. Muscle Nerve. 2017;56(6):1077-84. 